\title{
Impact of Nile cruise ships on the Environment
}

\author{
Samy S. Mahgoub
}

Associate Professor, Hotel Management Department, Egyptian Higher Institute for Hotels \& Tourism

\begin{abstract}
Although many hotels appear interesting in the natural environment to attract guests, a survey of Nile floating hoteliers finds that environmental stewardship has taken a backseat to other operational concerns in many cases. In addition, a survey was chosen to obtain the information on attitudes, awareness and practices of Nile cruise ships. Nevertheless, the surveyed hoteliers recognized that the floating hotel industry would do well to be more environmentally conscious. The respondents noted that few Nile cruise guests demand that hotels maintain environmental programs. The associations amongst attitudes, awareness and environmental practices for waste, energy, and the environment were investigated by calculating correlation coefficient. These analyses revealed that there is no significant association between attitudes and awareness or practices, while, medium between environmental awareness and environmental management practices. Attitudes appear to be remaining positive even where awareness is limited.
\end{abstract}

Keywords: Nile Cruise Ships; Environmental Attitudes; Environmental Awareness; Environmental Practices

\section{Introduction}

There are two types of touristic ships in Egypt, stable and mobile, The stable ships are called "Awamas" and exist on the banks of the River Nile in Cairo from Agouza to Imbaba. The other type is cruises that include floating hotels of three to five stories high, some cruise go along the Nile, and some others go on three-day trips from Aswan to Luxor.

All touristic ships must get a license from the concerned authorities to make sure they do not pollute the river stream. The law requires these ships to have containers to store sewage and waste, then dispose of them properly in specialized stations. Most of them however do not follow these necessary measures that are vital to protect the River Nile and just get rid of the waste in the river. The fuel to drive these ships is considered one of the main sources of Nile pollution, since some of it leaks in the water during maintenance or during fuel supply. The Awamas also dispose laundry materials into the Nile, most of which contain dangerous chemicals that can poison the fish and cause health issues to people. The Egyptian law bans all these wastes that threaten people's health and that authorities should focus on improving the cleanliness of the River Nile and eliminate these issues. According to the Egyptian Hotel Association (2014) reports, there are 286 cruise ships between Luxor and Aswan and dozens in Cairo. Water experts warned ship authorities of the disposal of waste many times before.

Environmental' issues have emerged as hot subjects in economic discussions since the early 1970s. So far, the term has usually been used for the analysis of exhaustible and productive resources. Lately, it is also being applied to amenity use of natural resources and in investigating the economic role of the environment and the associated causes and effects of its degradation and overuse, pollution, etc. Tourism is almost wholly dependent on the environment natural resources (beaches, seas, mountains, lakes, rivers etc.) and man-made resources (historic cities, heritage buildings and sites, monuments etc.) that constitute the primary source of tourism. Any degradation of these sources is likely to lead to a decline of tourism. Therefore, their analysis within economics is particularly relevant to tourism (Koncul, 2007).Growth and progress of the hotel industry in tourism destinations depend on the ongoing accessibility of natural resources. Hotels are enormous "consumers" of natural resources and hotel guests are often much less concerned with conserving resources such as water and power when they are away from home. Hotel operations therefore impact the environment in many different ways (Bohdanowicz, 2005).

\section{Environmental management}

Management of the environment has become a critical issue for the hotel industry in recent times in the wake of calls for a more responsible tourism development and the growing environmental awareness among tourists, associations, organizations and governments. This has led to the evolution of the green hotel movement which has become a new trend in the hospitality industry. As a new trend, environmental management has been vigorously pursued, especially by multinational hotels. This has given birth to 
international and regional initiatives, certification schemes and award of eco-labels which are used to encourage development of less damaging and environmentally friendly hotels as well as educating the customer.(Kuuder et al, 2013). In this light, it is therefore important that environmental management in hotels be placed in the framework of sustainable development since this will always result in a sustained tourism industry. Environmental management practices in hotels are usually geared towards energy conservation, water conservation, reduction of waste and establishing good relations with local communities. A result of cost savings that waste management, energy and water conservation have become popular environmental management practices (Kirk, 1998).

It has been realized that sound environmental management is beneficial to all hotels as it results in profitability, customer retention, improved corporate image and cost savings. In spite of the apparent positive impacts of hotels on the overall development of countries, they also exert pressure on the environment of destinations sometimes with dire consequences. Most of the studies on the impacts of hotels on the environment have been conducted on coastal and island resorts (Mensah, 2007). The goal of environmental management is protecting and preserving the environment and this has become increasingly important in the face of resource shortages, increasing costs and undesirable changes in climate and the environment (Bohdanowicz, 2006).

\section{Environmental attitude}

Environmental attitudes are defined as an individual's concern for the physical environment. Environmental attitudes are important because they often, but not always, determine behavior that either increases or decreases environmental quality. Traditionally, attitudes have cognitive, affective, and conative elements, but environmental attitudes might be better described as having preservation and utilization dimensions. Proenvironmental attitudes rise and fall with current events and vary with age, gender, socioeconomic status, nation, urban-rural residence, religion, politics, values, personality, experience, education, and environmental knowledge. Environmental education aims to improve environmental attitudes, but has mixed results (Gifford and Sussman, 2012; Clayton, 2012). Environmentally-friendly actions were the best measure of a traveller's desire to stay at a green hotel and spread positive opinions about it. Additionally, it was found that female and older customers who were already ecofriendly in their daily lifestyle opted primarily for eco-friendly hotels, were more willing to pay a premium, and had a higher probability of recommending it to others. The fact that consumer environmental attitudes are shifting towards increasing environmental responsibility, suggests that the growth of the market by personal endorsements appears to be favorable. (Han et al, 2011).

\section{Environmental awareness}

The concept of environmental awareness produced in the west in the 1960s includes mainly two aspects: the cognition of the environmental problems and the behavior orientation related to environmental protection (Zhang and Hou, 2014). While numerous factors make eco-certification appealing to hoteliers, it is important to identify what makes eco-certification appealing to consumers. Public awareness is one of the main obstacles to the successful implementation of sustainable practices in hotels. Solutions for increasing awareness could be to supply consumers with the tools necessary to identify the least environmentallydamaging practices, creating a market for green alternatives. Research has demonstrated that corporations who actively explained environmental issues in their hotels successfully encouraged their customers to pay for the services that come with a green hotel (Jhawar, et al, 2012).

Previous studies have defined environmental awareness as being made up of three components: environmental knowledge, environmental attitude and environmental behavior. Other research that has examined environmental problems and looked at the level of education in terms of awareness is conceptualized as beliefs, concerns and perceptions toward a particular environmental issue. Environmental action is seen as those simple steps that are reflected in everyday behaviors on the environment, for example, recycling, petition signing, attending meeting etc. environmental awareness (Baptiste, 2008).

\section{Pollution by cruise}

Air emissions from ship engines are an obvious source of pollution because many ships burn bottom-ofthe-barrel bunker fuel - typically what remains of the crude oil after gasoline and distillate fuel oils are extracted through refining. An estimated 60,000 people die worldwide each year as a result of underregulated shipping air emissions and that number is estimated to grow by 40 percent by 2012 due to increases in global shipping traffic. Conventionally a cruise ship's daily emissions are likened to the impact 
of 12,000 automobiles. It was found that bunker fuel on average has almost 2,000 times the sulphur content of highway diesel fuel used by buses, trucks, and cars and that one ship can make as much smog-producing pollution as 350,000 cars (Corbett et al, 2007).

Cruise ships like other ocean-going vessels use a tremendous amount of ballast water to stabilize the vessel during transport. This water is often taken on in one location after a ship discharges wastewater or unloads cargo and then discharged at the next port of call. [Ballast water]... typically contains a variety of biological materials, including plants, animals, viruses and bacteria. These materials often include nonnative, nuisance, exotic species that can cause extensive ecological and economic damage [and]... [pose] public health and environmental risks, as well as a significant economic cost to industries such as water and power utilities, commercial and recreational fisheries, agriculture, and tourism (Copeland, 2008).

Black water, otherwise known as human sewage, is the waste from cruise ship toilets and medical facilities. A cruise ship produces more than eight gallons of sewage per day per person. The Clean Water Act's provision for sewage discharges from vessels sets treatment standards that are inadequate, and now outdated, and does not require permits or reporting. Further, the discharge of sewage from vessels in coastal waters beyond three miles is not regulated (United States Environmental Protection Agency. 2008).

A typical large cruise ship will generate an average of eight metric tons of oily bilge water for each twenty-four hours of operation; according to the Royal Caribbean's 1998 Environmental Report its ships produce an average of 25,000 gallons of oily bilge water on a one week voyage. The risks posed to fish and marine organisms by oil and other elements in bilge water are great (Copeland, 2008).

After filtration of sewage, the solid part known as sewage sludge. It is estimated that 4.2 million gallons of sewage sludge are produced every year by ships as they pass through Washington State waters on their way to Alaska. Sewage sludge poses the same problem as sewage, but in a more concentrated form (National Marine Sanctuaries, 2008).

Gray water is wastewater from sinks, showers, galleys, laundry, and cleaning activities aboard a ship. It is the largest source of liquid waste from a cruise ship: as much as 90 gallons per day per person. Like sewage, gray water can contain a variety of pollutants. These include fecal coliform bacteria, detergents, oil and grease, metals, organic petroleum hydrocarbons, nutrients, food waste and medical and dental waste. The greatest threat posed by gray water is from nutrients and other oxygen-demanding materials. The cruise industry characterizes gray water as innocuous, at worst (Copeland, 2008).

A cruise ship produces a large volume of non-hazardous solid waste. This includes huge volumes of plastic, paper, wood, cardboard, food waste, cans, glass, and a variety of other wastes disposed of by the passengers. It was estimated in the 1990s that each passenger accounted for 3.5 kilograms of solid waste per day. Twenty-four percent of the solid waste produced by vessels worldwide comes from cruise ships. Food and other waste not easily incinerated is ground or macerated and discharged into the sea (Klein, 2009).

Toxic chemicals generated by cruise ships are generally waste products from photo developing, dry cleaning, painting and other activities. Under the Resource Conservation and Recovery Act, ships are required to store these wastes on board while under way, and then, once in port, to transfer them to certified chemical treatment and disposal facilities. Since this information is not made available to the public there's no way to ensure that each ship is complying with this requirement. Previously, some of these liquid hazardous wastes were simply mixed in with grey water and discharged without treatment. Now they are generally recognised as toxic wastes and treated accordingly (Vukadin, 2007).

World Health Organization (WHO) has reviewed identified over 100 disease outbreaks associated with ships between 1970 and 2000. Reported outbreaks included legionellosis, typhoid fever, salmonellosis, viral gastroenteritis, enterotoxigenic E coli infection, shigellosis, cryptosporidiosis and trichinosis. Naval, cargo and cruise vessels were all affected, often with serious operational and financial consequences. The WHO Guide to Ship Sanitation has become the official global reference on health requirements for ship construction and operation. Its purpose is to standardize the sanitary measures taken in ships, to safeguard the health of travellers and workers and to prevent the spread of infection from one country to another (World Health Organization, 2007).

The adoption of technologies to considerably reduce the impact of cruise ships on the environment is not only possible, but can be achieved at a relatively low cost. Installing systems to treat sewage in these vessels would represent some 2-2.2 million dollars per ship. To reduce the volume of waste, there are compacting, shredding, dehydrating and pulverising systems already available which make it easier to store and manage waste until it can be optimally treated (Oceana: protecting the world's oceans, 2004). 


\section{Energy consumption}

Energy saving has been considered one of the most significant areas of environmental management in the hotel industry because hotels in general consume a considerable amount of electricity and fossil fuel energy in various operational areas. According to the U.S Environmental Protection Agency (EPA), reducing energy use by 10 percent across the hospitality industry would save \$285 million (McLeish, 2007). Cruise ship tourism constitutes the most energy intensive form of tourism on a per tourist basis (Eijgelaar et al, 2010). The International Maritime Organization (IMO) estimated that in 2007 the global fuel consumption of passenger ferries and cruise ships was 31.3 million tonnes $(\mathrm{Mt})$, which corresponded to an approximate production of $96 \mathrm{Mt}$ carbon dioxide (Walnum, 2011)

A large part of the improvements in the environmental footprint of shipping is achieved through the efforts of the European marine equipment industry. A major challenge for the industry today is to 'transfer technology' from laboratories to ships, in order to reduce harmful emissions and gain the benefit to wider society. Investments in upgrading older ships are necessary to make them 'greener' and more efficient also in view of setting a benchmark for future new-buildings. A short term objective for the marine equipment sector is to be able to improve energy efficiency of ships by around 30\%. In the medium to long term, it has been estimated that a ship's energy efficiency can be improved by $60 \%$. These ambitious targets can, however, only be achieved by a continuous innovation process and through increased cooperation between the actors within the maritime cluster (European Marine Equipment Council, 2010). Heuristical researchers suggest people use simplifying strategies in order to make flexible and timely social decisions. Some might argue that there are endless ways in which can differentiate environmental beliefs, but there may also be a restricted number of company of commonly employed belief structures (Ryan and Spach, 2008).

\section{Problem statement}

According to records at Egyptian Hotel Association, Egypt has 286 floating hotels. The growth in hotels within the River Nile has sparked some concerns about their impact on the environment. This is in view of the fact that the benefits of tourism culminating in the springing up of these accommodation facilities are often accompanied by some negative environmental and social impacts. Concerns have been raised about the detrimental impacts of floating hotels on natural environments of River Nile. Floating hotels are also resource intensive and in order to reduce their negative impacts, it is imperative to adopt environmentally friendly activities in their management. One of the major international agreements relevant to cruise ship pollution is the International convention for the prevention of pollution from ships, as modified by the protocol of 1978, also known as MARPOL (marine pollution), or simply MARPOL. Six Annexes of the convention cover various sources of pollution from ships and provide a framework for international objectives (U.S. Environmental Protection Agency, 2008).

\section{Objectives}

The main objectives of this paper were:

- to investigate whether there is an association amongst cruise ships' attitudes, wareness of environmental issues and their environmental management practices;

- to identify environmentally friendly practices adopted by accommodation facilities to integrate the environment as a component of day-to-day floating hotel management;

- to measure the staff awareness, attitudes to the importance of environmental issues;

- to promote rational and eco-efficient use of resources;

- to give floating hotels the opportunity to make the first steps towards an integrated environmental management system.

\section{Methodology}

Nile cruise ships were selected for the survey since more than $20 \%$ of Egypt's hotel capacity is located in River Nile (Egyptian Hotels Association, 2014 and Central Agency for Public Mobilization and Statistics, 2014). A structured questionnaire was used to collect data on what firms are actually doing in relation to environmental issues (environmental practices), what hotel employees' belief regarding environmental issues and environmental protection (attitude) and their knowledge (awareness) of environmental management. Hoteliers were selected because they can participate in the process of enlightening customers, raising their environmental awareness and creating demand for "green" alternatives. Moreover, intention 
was to study whether there is any possible relationship amongst attitudes, awareness and environmental practices. The questionnaire was comprised of twenty three questions. Eight questions required the respondents to rank their answers using a 5- and 7-point Likert scale of importance. The questionnaire also contained three main clusters, focused on attitudes, awareness and practices. The questions included to find out more general information about employees' jobs. The questionnaire constructed with some open-ended questions pertained to barriers to implement environmental management practices for Nile cruises. The distribution of the questionnaire was conducted in person. Three hundred questionnaires were distributed to floating hotel employees while the number of respondents reached to one hundred and fifty four, resulting in a relatively low response rate (52\%). Respondents representing six Nile cruises included one, three and two of three-star, four-star and five-star floating hotels respectively.

The analysis of data was supported by coding the questionnaire; constructing scales and entering data to SPSS to calculate correlation coefficient while, Likert scale was used to scaling responses in the survey.

\section{Results and Discussion}

The profile of the participants belong to six Nile cruises is presented in Table (1).

The generally low ranking of environmental concern expressed by hoteliers may be interpreted as indicating a low interest in environmental issues among a majority of customers. Despite the perception that environmental concerns drive customer actions, this survey revealed that hoteliers do not consider environmental commitment to be a major marketing factor (Figure 1).

Table (1): Profile of Survey Participants

\begin{tabular}{|c|c|}
\hline Function or Position of the Respondent & Percentage \\
\hline Management & 13.0 \\
\hline Sales and marketing & 18.8 \\
\hline Food and Beverages & 14.9 \\
\hline Housekeeping & 19.5 \\
\hline Engineering & 15.6 \\
\hline Others & 18.2 \\
\hline $\begin{array}{l}\text { Total participants: } \\
\text { Star -rank of facilities: } \\
\text { - Five-star: 33.3\% } \\
\text { - Four-star: 50.0\% }\end{array}$ \\
\hline Three-star: $16.7 \%$
\end{tabular}

Figure (2) illustrates environmentaly-oriented initiatives, based on 7-point Likert scale. The study has indicated that if customers were to demand more environmentally sound performance from the floating hotel industry that demand would likely cause a substantial change in the industry. After the prospects of the demands of customers, reducing operational costs, ranked as the second-strongest incentive capable of encouraging hoteliers to undertake more environment-friendly activities. The desire to recommendations of management was in the third place, followed by the will to availability of professional advice. Due to customers' apparent indifference, hoteliers are currently assigning ecofriendliness a low priority in their marketing efforts. If clients do not look for or ask about hotel's environmental aspects, these aspects are not improving the hotel image. Notably, marketing asset as an incentive to be more active in environmental issues ranked low Nor were the diminishing environmental impacts of the hotel found to be a sufficient incentive to enhance eco-friendliness. These findings have serious implications for the prospects of introducing environmental sustainability into the floating hotel industry. The study indicates two conditions that need to be fulfilled. First, the cost savings associated with environment oriented initiatives must be widely demonstrated within the sector. Second, there is a need to raise awareness of and initiate or create demand for "green" alternatives among the customers. 


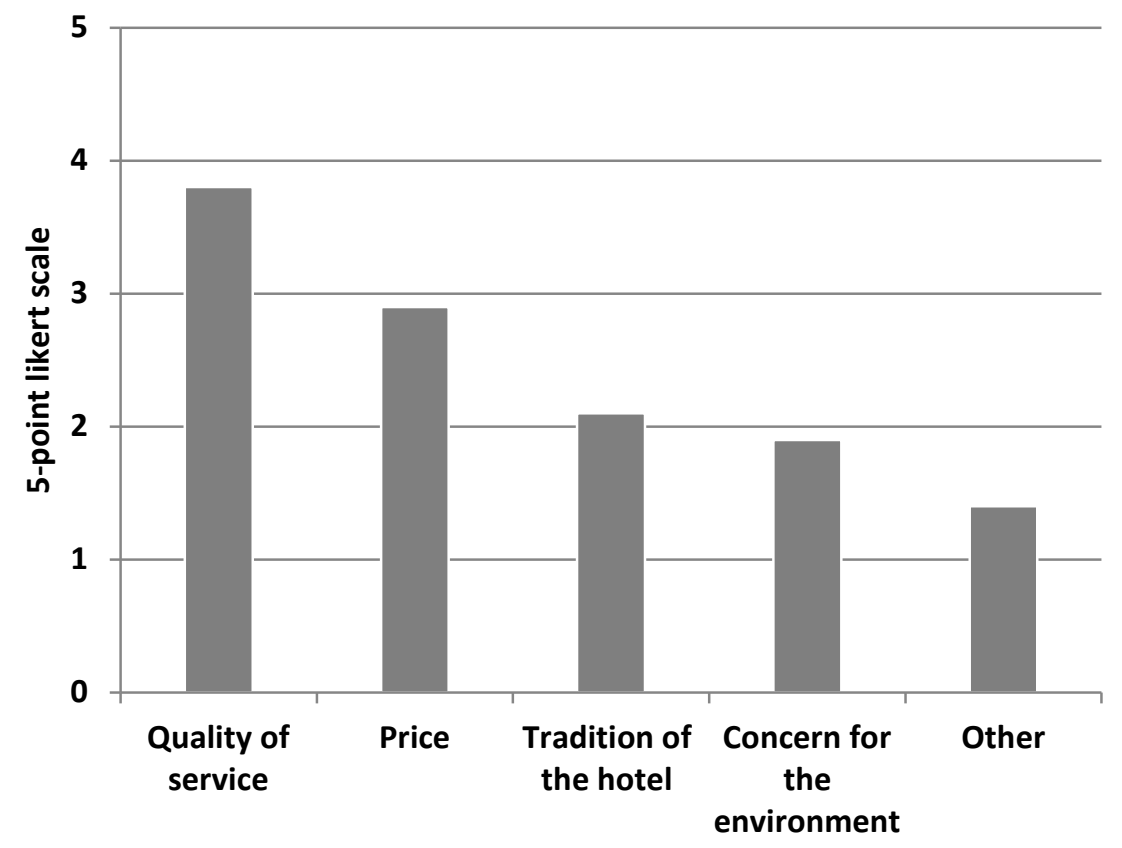

\section{Figure (1): Hotel features and their perceived importance to guest decision making for selection of lodging establishments}

Responses in Tables (2), (3) and (4) attributed to the total responses for each question. According to the Table (2) the respondents expressed highly positive attitudes concerning the importance of environmental issues and the responsibilities of business with regard to these issues. However, their positive attitude does not appear to be reflected in either their awareness of key information on environmental management (Table 3). The low awareness of the ecolabels for the Nile cruises, among hoteliers indicates lack of promotion. Along that line, organizations devoted to disseminating environment related information within the hotel sector, hotelier initiative, are barely known among the cruise employees. This particular finding indicates that the environmental institutions and governments that want to promote environment friendly and sustainable policies need to focus more on and intensify their efforts in informing and reaching unaffiliated hotels. They should also continue to disseminate information among the brand associated establishments. A number of possible ways to achieve this goal will be presented later. Table (4) illustrates hotelier environmental practices, which highlights almost non-environmental practices. It has been estimated that roughly 75 percent of the environmental impact related to the lodging industry originates from the consumption of nondurable goods (and consequent waste generation), as well as the use of energy and water (Bohdanowicz, 2005).

The associations between attitudes, awareness and practices were investigated by calculating correlation coefficient (Table 5). These calculations revealed that there is little or no significant association between attitudes and awareness or between attitudes and practices. In other words, attitudes appear to be remaining negative, even where awareness is limited. Hoteliers with rather more positive awareness appear less likely to introduce environmental management practices for their organizations than those with attitudes. 


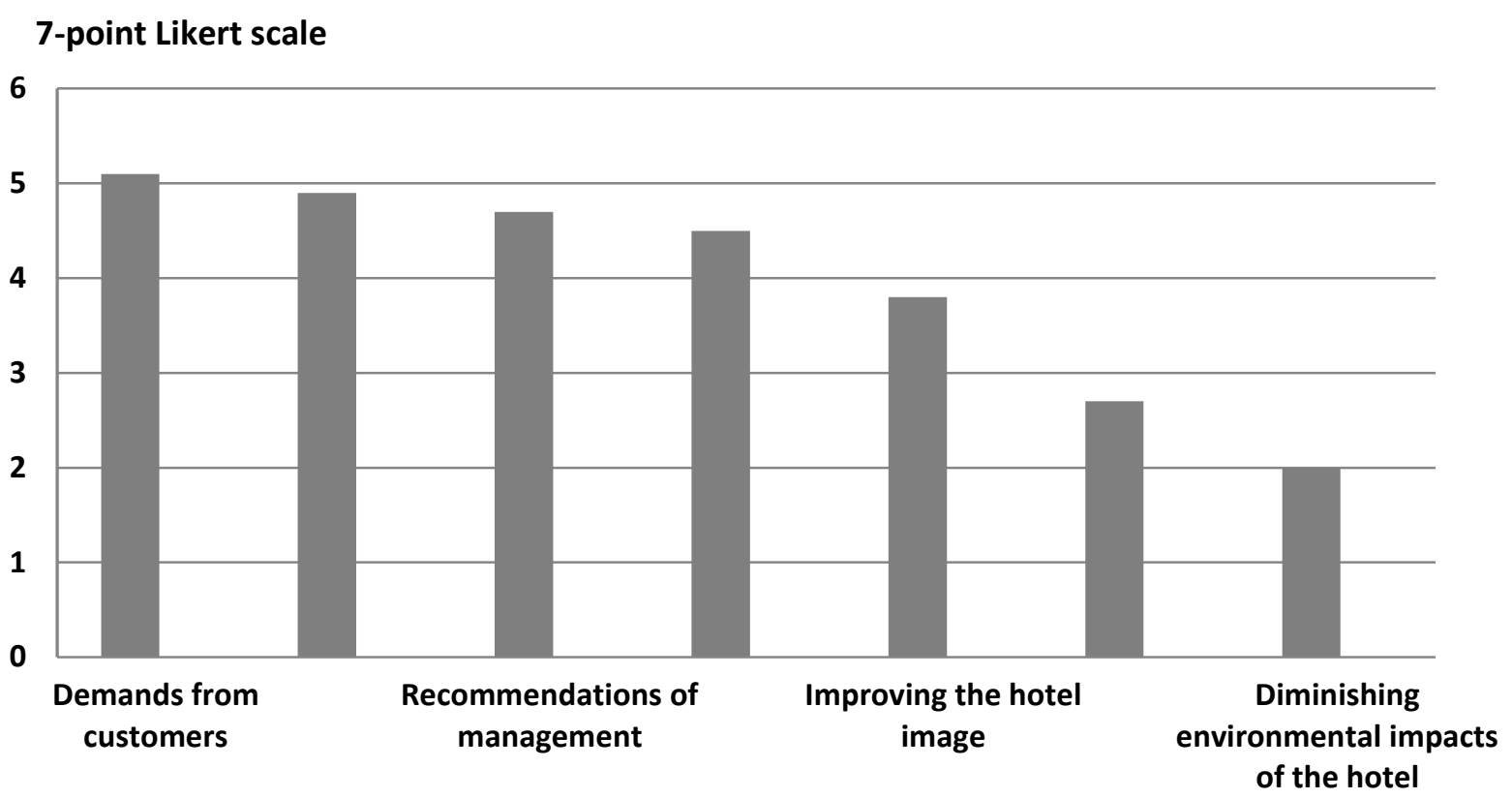

Figure (2): Incentive factors to introduce more environment-friendly initiatives

Table (2): Responses to questions about attitude

\begin{tabular}{|l|c|}
\hline \multicolumn{1}{|c|}{ Responses } & Percentage \\
\hline $\begin{array}{l}\text { Agreed or Strongly agreed that 'Good environmental management is an } \\
\text { essential part of business management' }\end{array}$ & 76 \\
\hline Disagreed or Strongly disagreed that 'Energy efficiency is not important & 72 \\
\hline $\begin{array}{l}\text { Agreed or Strongly agreed that 'All business have a responsibility to } \\
\text { protect the environment' }\end{array}$ & 50 \\
\hline $\begin{array}{l}\text { Disagreed or Strongly disagreed that 'Waste minimization is a waste of } \\
\text { time' }\end{array}$ & 53 \\
\hline $\begin{array}{l}\text { Agreed or Strongly agreed that 'Waste minimization is important for } \\
\text { environmental reasons' }\end{array}$ & 65 \\
\hline $\begin{array}{l}\text { Agreed or Strongly agreed that 'Every business has a responsibility } \\
\text { to minimize the waste they produce' }\end{array}$ & 94 \\
\hline
\end{tabular}

Table 3: Responses to questions about awareness

\begin{tabular}{|l|c|}
\hline \multicolumn{1}{|c|}{ Responses } & Percentage \\
\hline Unaware of local programme conducted regarding waste management? & 53 \\
\hline $\begin{array}{l}\text { Unaware of that local authorities have a role to play in the management } \\
\text { of waste? }\end{array}$ & 59 \\
\hline
\end{tabular}




\begin{tabular}{|l|c|}
\hline Unaware of the principle of waste minimization & 47 \\
\hline Unaware of e-waste & 76 \\
\hline Unaware of the effective mechanism for waste management & 41 \\
\hline Unaware of the complications of improper waste management & 71 \\
\hline
\end{tabular}

Table 4: Responses to questions about environmental practices

\begin{tabular}{|l|c|}
\hline \multicolumn{1}{|c|}{ Responses } & Percentage \\
\hline Have been introduced some kind of environmental management system & 24 \\
\hline Separate waste to several categories & 41 \\
\hline Have written environmental policy & 12 \\
\hline Have taken any action in order to decrease electric energy consumption & 24 \\
\hline Have implemented any of energy saving measures in cruise ship & 18 \\
\hline $\begin{array}{l}\text { Have noticed any information in the media regarding rational energy } \\
\text { consumption by increasing energy efficiency }\end{array}$ & 35 \\
\hline
\end{tabular}

However, there is some associations between awareness and practice; and between practices relating to energy and waste management. In other words, knowing (awareness) and doing (practice) seem to go together.Nile cruise ships' employees have limited awareness of business issues relating to environmental management and have not adopted management practices designed to improve their environmental performance that generates concern about Nile pollution. As far as attitudes and awareness are concerned, the research concludes to provide an insight that there is a substantial gap between them and environmental practices. This study has indicated that the prospect of significant customer demand as well as cost saving are currently the most likely parameters to enhance environmental responsibility among hoteliers. Undoubtedly a great need remains for increasing environmental knowledge and awareness among hoteliers and the general public.

Table 5: Correlations between attitudes, awareness and practices

\begin{tabular}{|c|c|}
\hline Two Variables & Correlation coefficient (r) \\
\hline Environmental attitudes and awareness & -0.38902 \\
\hline Environmental attitudes and practices & -0.21934 \\
\hline Environmental awareness and practices & 0.542197 \\
\hline
\end{tabular}

\section{Conclusion}

- Some of the identified characteristics of the Nile cruise ships which contribute to poor levels of environmental control operations are:

- Lack of understanding of environment, public health and safety issues.

- Poor business planning without following the sustainable development framework due to lack of guidance.

- Limited awareness of legal and regulatory obligations.

- Poor environment practices due to non- regularized labor practices. 
- Non adoption of cleaner technologies or use of expensive pollution control equipment due to low economies.

- Poor compliance monitoring by the responsible agencies.

\section{Recommendations}

In the light of the findings of the present study, the investigator would like to recommend the following:

- It is very essential through environmental education to promote awareness of environmental concerns and legislations amongst employees and the surrounding community.

- Conduction in-depth assessment of the volumes and characteristics of the spectrum of waste streams from cruise ships with analysis of their potential impact on water quality, Nile environment, and human health.

- Nile cruise ships should constitute some kind of attention and reasonable set of initiatives pertained to the problem in the field of environmental management whilst there is an obvious gap between Nile cruises and Egyptian government in the context of managing the environmental performance.

- Floating hotels can make environmental management operational using a wide range of measures designed to minimise the firm's impact on the environment, this would include modifying processes in hotel's services production system, as well as talking account of volume and type of waste generated and its potential danger.

- The environmental institutions and governments that want to promote environment-friendly and sustainable policies need to focus more on and intensify their efforts in informing and contacting floating hotels. They should also continue to disseminate information among the brand associated establishments.

- Customers' environmental awareness needs to increase so that guests issue a greater demand for "green" practices. Hoteliers can also participate in the process of enlightening customers, raising their environmental awareness and creating demand for "green" alternatives.

- To achieve more environmentally responsible behavior in the cruise ship sector, it is necessary to further demonstrate the cost savings associated with such practices. Cost- benefit analyses should, therefore, be performed and the findings widely disseminated, and new or less expensive technologies should be developed to facilitate the process.

- Environmental organizations and hotel companies, should develop and offer special training courses for the cruise ship sector. If organizations do not offer educational or advisory services, representatives of the industry should put pressure on them to do so.

- To protect environmental quality to a greater extent, for example, by including certain environmental requirements in the floating hotel standardization procedures.

- Environmental objectives and targets must be spelled out, regularly updated and communicated to the parties involved. They must respect the environmental policy of the company focusing on the preventive approach.

- Examination of existing federal regulations governing cruise ship waste streams.

- Recommendations have to be formulated on how to better control and regulate waste streams.

\section{References}

Baptiste, A. K. (2008). Evaluating environmental awareness: a case study of the Nariva Swamp, Trinidad, Ph.D. thesis, New York university, New York, USA.Bohdanowicz, P. (2005). European hoteliers' environmental attitudes: greening the business: Cornell Hotel and Restaurant Administration Quarterly, 46(2) 188. Bohdanowicz, P. (2006). Environmental awareness and initiatives in the Swedish and Polish hotel industries-survey results. International Journal of HospitalityManagement, 25(4) 662-682.

Clayton,

S. D. (2012). The Oxford Handbook of Environmental and Conservation Psychology, 3-5. Oxford University Press, New York, USA.

Copeland, C. (2008). Cruise Ship Pollution: Background, Laws and Regulations, and Key Issues. Washington, DC: Congressional Research Service (Report \#RL32450

https://wikileaks.org/wiki/CRS:_Cruise_Ship_Pollution:_Background,_Laws_and_

Regulations,_and_Key_Issues,_November_17,_2008 (Accessed: Nov. 18, 2013).

Corbett, J.J.; Winebrake, J. J.; Green, E. H.; Kasibhatla, P.; Eyring, V. and Lauer, A. (2007). "MortalityfromShipEmissions:AGlobalAssessment,"p8512,8514, http://pubs.acs.org/doi/full/10.1021/es071686z (Accessed: Nov. 12, 2014).

Egyptian Hotels Association (2014). Hotel Guide, Dokki, Giza.

Eijgelaar E.; Thaper C. and Peeters P. M. (2010). Antarctic cruise tourism: The paradoxes of ambassadorship, "last chance tourism" and greenhouse gas emissions. Journal of Sustainable Tourism. 2010;18:337-354. 
Environmental Protection Agency (2008). Cruise Ship Discharge Assessment Report. Washington, D.C. 20460, USA. European Marine Equipment Council (2010). Green Ship Technology Book, Existing Technology by the Marine Equipment Industry: A contribution to the reduction of the environmental impact of shipping. http://www.oecd.org/sti/ind/48365856.pdf (Accessed: July 15, 2014)

Gifford, R and Sussman, R. (2012). Environmental Attitude. The Oxford Handbook of Environmental and Conservation Psychology. https://global.oup.com/academic/product/the-oxford-handbook-of-environmental- andconservation-psychology-9780199733026?cc=eg\&lang=en,(Accessed:Oct.11,2014).

Han, H.; Hsu, L.T.; Lee, J.S.and Sheu, C (2011). Are lodging customers ready to go green? An examination of attitudes, demographics, and eco-friendly intentions. International Journal of Hospitality Management 30, 345-355. Jhawar, A.; Kohli, G.; Li, J.; Modiri, N.; Mota, V.; Nagy, R.; Poon, H. and Shum, C. (2012). Eco-Certification Programs for Hotels in California: Determining Consumer Preferences for Green Hotels, Undergraduate Program of Institute of the Environment and Sustainability University of California, USA.Kirk, D. (1998). Attitudes to environmental management held by a group of hotel Management, 17:33-47.

Klein, R. A.(2009). Getting a Grip on Cruise Ship Pollution. Friends of the Earth, http://www.cruisejunkie.com/FOE.pdf (Accessed: September 11, 2014).

Koncul, N. (2007). Environmental issues and tourism, EKON. MISAO PRAKSA DBK. GOD XVI. BR. 2.(157-166) Kuuder, C-J.W., Bagson, E., Prempeh, V. M., Abu Mummuni,Abongo, R. and Amoako, E. E. (2013). Energy, Water and Waste Management in the accommodation sector of Tamale Metropolis, Ghana.AmericanJournalofTourismManagement2013,2(1A):1-9

McLeish, B. (2007). Pairing green design with energy purchasing strategies: Hospitality . construction, 2(6): 52-54. Mensah, I. (2007).Environmental management and sustainable tourism hotels in Greater Accra Region (GAR) of Ghana. Journal of Retail and Leisure Property, 6:15-22.

National Marine Sanctuaries (2008). Olympic Coast Marine Sanctuary: Condition Report 2008, Washington, DC: NOAA. p. 43.

http://olympiccoast.noaa.gov/library/docs/conditionreport_ocnms.pdf (Accessed: Oct. 21, 2014).

Oceana: protecting the world's oceans (2004). Contamination by cruise ship.

reports/publications/reports/contamination-bycruise-ships

(Accessed: http://oceana.org/en/eu/mediainterpretations. The Commonwealth Scientific and Industrial Research Organisation (CSIRO), Clayton South, Australia.

United States Environmental Protection Agency (2008). Cruise Ship Discharge Assessment Report, Washington, DC: Environmental Protection Agency, pages 6-3 - 6-14.

http://water.epa.gov/type/oceb/upload/0812cruiseshipdischargeassess.pdf (Accessed: Nov. 12, 2014).

Vukadin, I. (2007). Protect our seas from cruise pollution, Croatia Šetalište I Meštrovia 63, 21000 Split, Croatia.

Walnum, H. J. (2011). Energy use and CO2 emissions from cruise ships - A discussion of methodological issues. Vestlandsforsking Western Norway Research Institute. http://www.vestforsk.no/filearchive/vf-notat-2-2011-cruise.pdf (Accessed: Nov.20, 2014).

World Health Organization (2007). International Health Regulations Guide to Ship Sanitation Report, 19-23. 20 Avenue Appia, 1211 Geneva 27, Switzerland Zhang, L.and Hou, X. (2014). Analysis on the factors that affect the effectiveness of Chinese public participation in environmental protection. International Protection, Hong Kong,China.

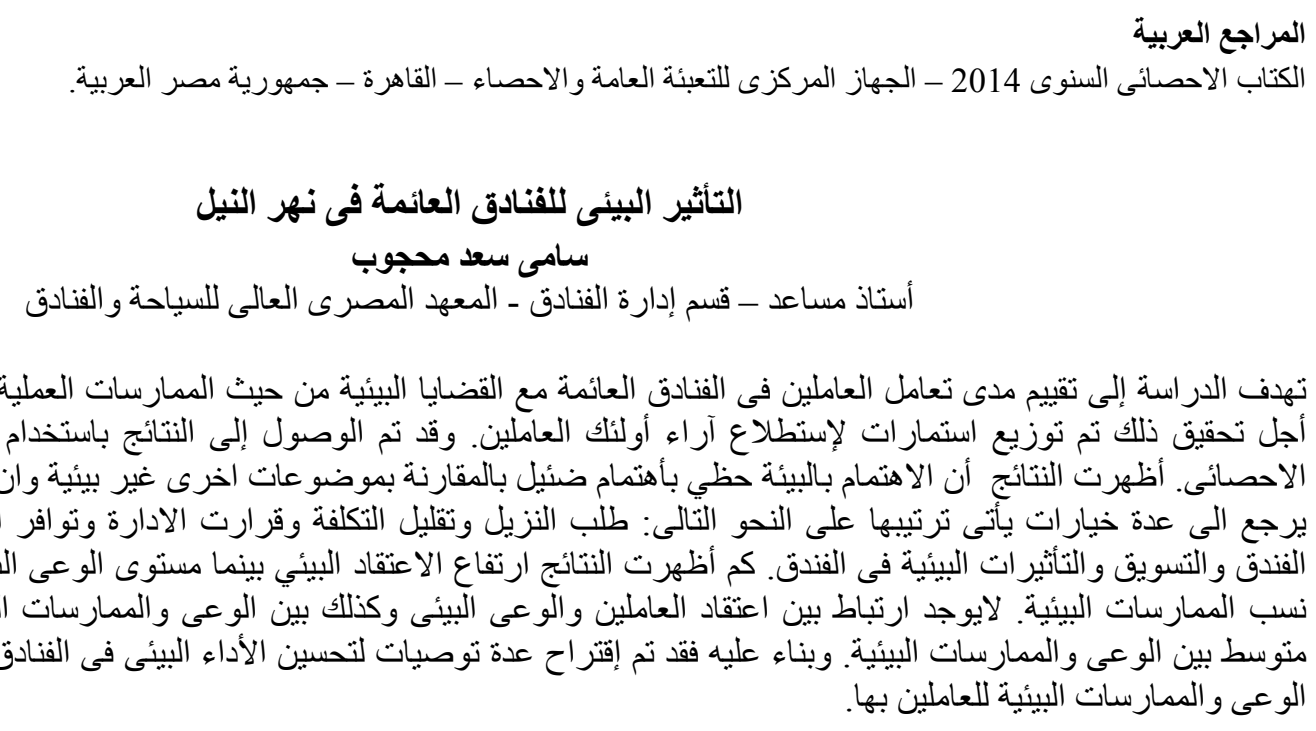

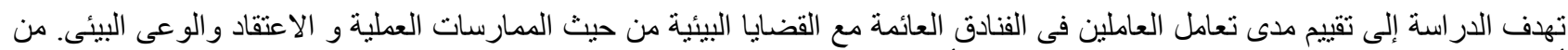

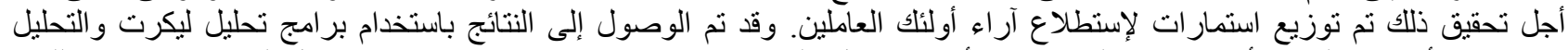

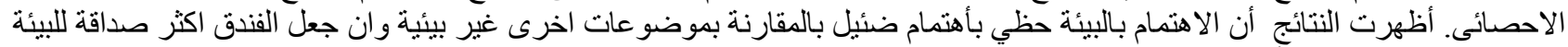

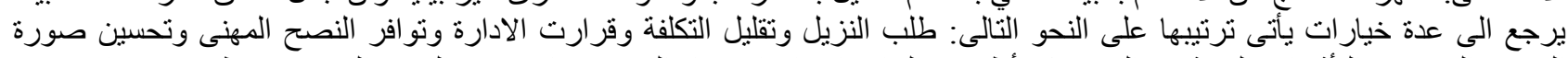

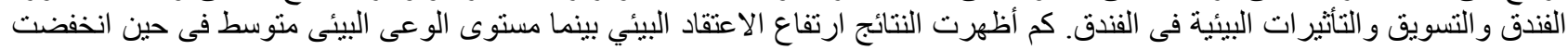

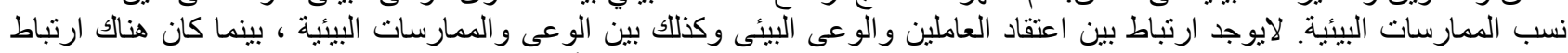

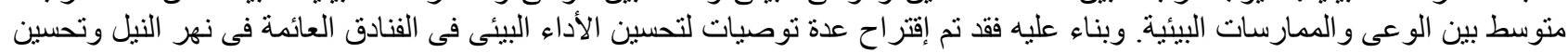
الوعى و الممارسات البيئية للعاملين بهات البياتة وسئ. 